\title{
RESPONSE OF YOUNG SOUR CHERRY TREES TO WOODCHIP MULCH AND DRIP IRRIGATION
}

\author{
Daina Feldmane \\ Latvia State Institute of Fruit Growing \\ 1 Graudu St, Dobele, LV 3701, Latvia \\ Ph.: +(371)26439025, e-mail: daina.feldmane@inbox.lv
}

\begin{abstract}
The productivity of sour cherries grown in Latvia is insufficient. Yielding of sour cherries can be advanced providing appropriate soil moisture and control of diseases. Cherry leaf spot as well as spur and twig blight are the most important sour cherry diseases which cause economical losses of the yield. The influence of woodchip mulch and drip irrigation on sour cherry yielding and resistance to the diseases is investigated. The drip irrigation and woodchip mulch increased the yield of cherries. The cultivar 'Bulatnikovskaya' was the most productive. Drip irrigation slightly improved resistance to cherry leaf spot for the cultivars 'Zentenes', 'Orlica' and 'Tamaris'.
\end{abstract}

Keywords: sour cherries, woodchip mulch, drip irrigation, spur and twig blight, cherry leaf spot.

\section{Introduction}

Sour cherries are distributed fruit plants in Latvia. Productivity of the sour cherries is about $5-7 \mathrm{t} / \mathrm{ha}$ in the countries where they are grown intensively [16]. Sour cherries often are less productive in Latvia conditions. The diseases of sour cherries are one of the factors decreasing productivity. Cherry leaf spot as well as spur and twig blight cause significant losses of the yield $[1,11]$.

Spur and twig blight can be caused by fungus Monilinia spp. as well as by bacteria Pseudumonas spp.

The fungus Monilinia spp. infects blossom parts, and through the floral tube and pedicel moves into the spur or twig [3]. Monilinia species over-winter on spurs, twigs, cancers and mummies of fruits where the conidia form in the early spring at the temperatures of $5^{\circ} \mathrm{C}$ or higher. Conidia are disseminated by wind and rain and germinate rapidly under favourable conditions. The incidence of blossom blight caused by M. fruticola Honey is related to the temperature and the duration of wetness; as little as $3-5$ hours of wetting at $20^{\circ} \mathrm{C}$ may lead to significant infection. Optimum temperature for blossom infection is $25^{\circ} \mathrm{C}$. In general, within the range of $5-30^{\circ} \mathrm{C}$, temperatures above or below the optimum delay the infection but do not prevent it. The infection and development of fungus M. laxa Honey occur during periods of wetness at temperatures above $13^{\circ} \mathrm{C}$ (optimum $24^{\circ} \mathrm{C}$ ). The disease incidence increased with longer wetness duration [17].

The bacteria Pseudumonas spp. overwinter in cankers and buds and systemically inside other symptomless host tissue [3]. Periods of frequent rainfall, high humidity, cool temperatures, and wind favour dispersal and infection of the pathogens Infected dormant buds often died, but some invaded buds open normally in spring. The leaves, blossoms and the fruits from these buds wilt. Cankers can develop on twigs at the base of infected spurs. The bacteria colonize new leaves in the spring and grow also epiphytically on weeds and leaves of crop plants. After entering through stomata, the pathogens colonize intercellular spaces of the spongy parenchyma and moves through the parenchyma to axillary buds and to the twigs. Optimal temperature range for visible symptom development on plants is $15-25^{\circ} \mathrm{C}$ [15]. In vitro estimated temperature optimum was $28^{\circ} \mathrm{C}$, but no significant differences of growing rate were observed in temperature range from 23 to $33^{\circ} \mathrm{C}$ [19]. It was noted that Pseudomonas syringae grew well at low temperatures too. 
Cherry leaf spot is caused by the fungus Blumeriella jaapii Rehm. [3]. Visible symptoms appear as small reddish spots on the upper surface of the leaves. Infected leaves turn yellow, and defoliation may result. The infection of fruit pedicels is possible when weather conditions are optimum for the disease. The fruits on severely defoliated trees fail to mature normally. The fungus Blumeriella jaapii Rehm. over-winters in the infected leaves where the apothecia are produced in the spring. The optimum temperature for apothecial development is 13 $16.5^{\circ} \mathrm{C}$. The ascospores may be discharged during and shortly after the rainfall from late bloom to about six weeks after petal fall. Ascospore discharge is the highest at $16-30^{\circ} \mathrm{C}$, less at $12^{\circ} \mathrm{C}$ and lowest at $4-8^{\circ} \mathrm{C}$. The fungus infects the leaves of the cherries through stomata. A wet period only a few hours is required for spore germination and infection when temperatures are $15-20^{\circ} \mathrm{C}$. The fungus Blumeriella jaapii Rehm. produce the acervuli, which contain the conidia on lower surface of the leaves. The conidia are developed in $5-15$ days, and the lesions became visible. The conidia are discharged during rainy weather conditions. Repeated secondary infection by the conidia continues until leaf fall in the autumn.

The control of the diseases by spraying of the pesticides is limited for the sour cherries. Cherry fruits ripen for a short time and it is difficult to protect cherry fruits from pesticide residues. Several researches were done to deal this problem. In Bulgaria the control of cherry leaf spot by decreased number of pesticide sprayings was investigated [1]. Such control of cherry leaf spot was successful if both preventive and curative treatments were done, and long periods of wetness were absent. In Germany, susceptibility for Monilia sp. and Blumeriella jaapii Rehm. was tested for 24 sour cherry cultivars under organic cultivation methods [11]. Similarly, the susceptibility of sour cherries was significantly influenced by weather conditions in vegetation season. The cultivars 'Rubellit' and 'Hortei' had low susceptibility to diseases and high productivity even if the conditions were favourable for the infection.

Pathogens $M$. laxa and $M$. fruticola have antagonist fungi Trichoderma spp., it makes biological control possible [6]. The effect of microbial plant growth promoter based on fungus Trichoderma asperellum on the development of fungus Monilia was investigated [9]. About $50 \%$ reduction of symptoms of blossom and spur blight was observed on treated trees (the cultivar 'Lutovka'). It was additionally noted that the aphids avoided to colonize the treated branches contrary to untreated. The obtained yield was threefold increased comparing to the control.

The susceptibility of cherries to the diseases is significantly varied by the cultivar $[1,11]$, consequently the cherries have genetically stated preventive responses to diseases. The water is related in plant responses to the environmental stress factors [2]. Positive response of soil moisture regulation to sour cherry productivity is observed in several reserches. Straw and moved grass mulch significantly increased the yield of sour cherry cultivar 'Montmorency' in Mitchigan [13]. Additionally, the amount of leached nitrogen was decreased in the mulch variant. Drip irrigation increased yield of sour cherry cultivar 'Lutovka' in Poland [8, 12]. Water is involved in all essential living processes of the plant as transport of nutrients, photosynthesis etc. It is supposed that practices reducing the stress through good nutrition or proper soil moisture can increase tolerance to diseases [3]. Contrary, the advanced growing due to favourable soil moisture can lead also to dense canopy which is appropriate for disease development [6]. There is no information about water supply relation to susceptibility of sour cherries to diseases. The aim of the research is to evaluate the influence of woodchip mulch and drip irrigation to the sour cherry productivity and susceptibility to cherry leaf spot as well as to spur and twig blight in Latvia. 


\section{Materials and methods}

The trial was established at the Latvia State Institute of Fruit Growing in Dobele in 2007. The treatments were arranged in a split plot design: the method of soil moisture treatment - on the main plots, the cultivars - on the split plots. The factor - method of soil moisture treatment had three variants:

- using of woodchip mulch in the tree strips, thickness of woodchip layer was $10 \mathrm{~cm}$,

- drip irrigation which moistens soil in $1 \mathrm{~m}$ wide tree strips,

- the control - neither mulch nor irrigation in the tree strips.

There were three replications both per mulch and control variants, and four replications per the irrigation variant. Seven sour cherry plants (one of each cultivar) were planted in every replication. The factor - cultivar of sour cherries had the following variants: 'Latvijas Zemais', 'Zentenes', 'Tamaris', 'Bulatnikovskaya', 'Desertnaja Morozovoi', 'Orlica', and 'Shokoladnica'.

The trial was established on clay Podzoluvisol soil which was slightly acid $-\mathrm{pH}$ 6.4. The content of $\mathrm{P}$ was $53 \mathrm{mg} \mathrm{kg}^{-1}$, content of $\mathrm{K}$ was $124 \mathrm{mg} \mathrm{kg}^{-1}$. Sour cherries were planted in spring of 2007 at distances of $4 \times 4 \mathrm{~m}$. The fertilizers were given yearly as $12 \mathrm{~g} \mathrm{~m}^{-2}$ of N, $5 \mathrm{~g}$ $\mathrm{m}^{-2}$ of $\mathrm{P}$, and $10 \mathrm{~g} \mathrm{~m}^{-2}$ of $\mathrm{K}$ in the tree strips. Nitrogen fertilizer was given in the spring (in April), phosphorus and potassium ferilizers were given in the autumn. Weeds were controlled both by removing them and spraying with herbicide Basta (active ingredient glufosinateammonium) in $1 \mathrm{~m}$ wide strips along the trees. Perennial grasses were sown in the space between strips. The diseases were controlled by spraying:

1) fungicide Champion (active ingredient cooper hydroxide) at beginning of second decade of April,

2) fungicide Efector (active ingredient dithianon) at first decade of May and at beginning of first decade of August,

3) fungicide Topas (active ingredient propiconasole) at beginning of third decade of May.

Soil moisture was measured with device Theta Probe type ML2x once during 7-11 days. In the variant with drip irrigation, soil moisture was provided at about 70 per cent of the field water capacity. In Dobele, the total amount of precipitation during the period of active vegetation was $275 \mathrm{~mm}$ in 2009, and the sum of active temperatures was $2454^{\circ} \mathrm{C}$ (based on data of Latvian Agency of Enviroment, Geology and Meteorology). The weather conditions were dry in May. In 2009, irrigation was done 12 times and the total amount of water was 876 $\mathrm{L}$ per a $4 \mathrm{~m}$ long tree strip. In 2010, the total amount of precipitation during the period of active vegetation was $556 \mathrm{~mm}$ and the sum of active temperatures was $2604^{\circ} \mathrm{C}$. Drip irrigation was not done in this year because soil was moist during all season.

The susceptibility for diseases was evaluated in 2009 and 2010. The infected twigs and blossom clusters were counted at the end of May in order to evaluate twig and blossom blight. Afterwards the infected parts were removed from trees. The susceptibility to cherry leaf spot was evaluated at the middle of September. The scala of 5 degrees was used:

0 - cherry leaf spot did not cause defolation or decoloration of leaves,

1 - less than $25 \%$ of leaves had fallen

2 - about $25 \%$ of leaves had fallen,

3 - about $50 \%$ of leaves had fallen,

$4-$ about $75 \%$ of leaves had fallen,

5 - all leaves had fallen.

The yield was characterized as total amount of fruits $(\mathrm{kg})$ per tree in 2010 . The data were statistically processed using analysis of variance and Duncan's test for post hoc analysis. The relationships between disease susceptibility and cherry yield were calculated using Spearman's correlation. This calculation was done for each cultivar separately because yield differences among cultivars were significant. 


\section{Results}

In general, drip irrigation and woodchip mulch advanced the yielding of sour cherries. The intensity of this influence differed depending on yielding habit of the cultivar. Most of sour cherry cultivars are yielding on twigs and on spurs.

The cultivars 'Latvijas Zemais', 'Shokoladnica' and 'Desertnaya Morozovoi' mainly yielded on the twigs - on the shoots grown up in the previous season of the vegetation [4]. The woodchip mulch did not influence the vegetative growth of sour cherries in second growing year (in 2008) significantly. Decreased yielding but essential increase of growth caused by woodchip mulch was observed in third growing year (in 2009). Accordingly, advanced vegetative growth in 2009 provided significantly higher yield in next year (in 2010) for the cultivars Latvijas Zemais', 'Shokoladnica' and 'Desertnaya Morozovoi' in the woodchip mulch variant (on average, $1.5 \mathrm{~kg}$ per tree) comparing with control variant (on average $0.5 \mathrm{~kg}$ per tree) (Table1). The yield of these cherry cultivars grown with drip irrigation (on average $0.9 \mathrm{~kg}$ per tree) did not differ significantly with other variants.

Table 1.

Influence of woodcip mulch and drip irrigation on sour cherries yielding on the twigs

\begin{tabular}{|l|l|l|l|}
\hline \multirow{2}{*}{ Factors } & \multicolumn{3}{|c|}{ Yield, kg per tree } \\
\cline { 2 - 4 } & \multicolumn{1}{|c|}{ Woodchip mulch } & \multicolumn{1}{c|}{ Drip irrigation } & \multicolumn{1}{c|}{ Control } \\
\hline 'Shokoladnica' & 2.23 & 1.47 & 0.61 \\
\hline $\begin{array}{l}\text { 'Desertnaya } \\
\text { Morozovoi' }\end{array}$ & 1.01 & 0.53 & 0.55 \\
\hline 'Latvijas Zemais' & 1.11 & 0.59 & 0.20 \\
\hline On average & $1.45^{\text {a }}$ & $0.86^{\text {ab }}$ & $0.45^{\mathrm{b}}$ \\
\hline
\end{tabular}
- the means in the rows marked with the same letter did not differ significantly at $\mathrm{P} \leq 0.05$

The cultivars 'Orlica', 'Zentenes' and 'Tamaris' have high proportion of the spurs in their canopy [4]. The spurs are short fruiting branches which develop on two years old shoots. In 2010 yielding spurs developed in 2009 on the shoots which grew up in 2008. Drip irrigation increased vegetative growth of sour cherries in first growing years - both in 2008 and 2009. So the development of the spurs and following yielding was advanced (Table 2). The cultivars 'Orlica', 'Zentenes', 'Tamaris' and 'Bulatnikovskaya' had tendency to increase yield $(\mathrm{p}=0.1)$ in the variant with drip irrigation (on average, $1.7 \mathrm{~kg}$ per tree) comparing to control and woodchip mulch variants (on average, 1.0 and $1.1 \mathrm{~kg}$ per tree, respectively).

Table 2.

Influence of woodcip mulch and drip irrigation on sour cherries yielding on the spurs

\begin{tabular}{|l|l|l|l|}
\hline \multirow{2}{*}{ Cultivars } & \multicolumn{3}{|l|}{ Yield, kg per tree } \\
\cline { 2 - 4 } & Drip irrigation & Woodchip mulch & control \\
\hline 'Bulatnikovskaya' & 3.65 & 2.87 & 2.40 \\
\hline 'Zentenes' & 1.40 & 0.72 & 0.91 \\
\hline 'Orlica' & 1.13 & 0.73 & 0.48 \\
\hline 'Tamaris' & 0.67 & 0.20 & 0.14 \\
\hline On average & $1.71^{\text {a }}$ & $1.13^{\text {a }}$ & $0.99^{\text {a }}$ \\
\hline
\end{tabular}

The yielding was essentially influenced also by cultivar. The most productive was the cultivar 'Bulatnikovskaya' - the average yield was $3.0 \mathrm{~kg}$ per tree. The yield of the other cultivars (with exception of cultivar 'Tamaris') ranged from 0.6 to $1.5 \mathrm{~kg}$ per tree and did not differ significantly each with other in 2010. 


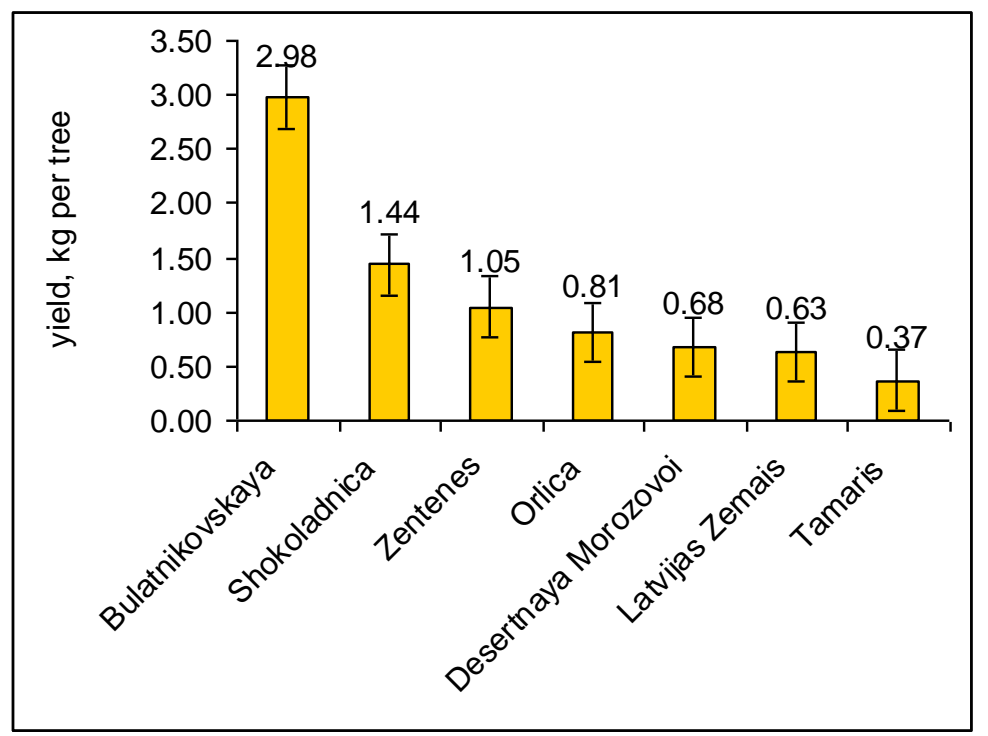

Fig. 1. Yield of sour cherry cultivars in 2010

In generally, yield of sour cherries was not high in 2010. One of the reason was insufficient fruit set, but low productivity of the cultivar 'Tamaris' was caused by low vigour of the tree and by damaged flower buds in the winter.

Dry weather conditions in May of 2009 were unfavourable for Monilinia spp. and Pseudomonas spp. development. The incidence of spur and twig blight was very low - only few infected blossoms in the orchard.

Warm and wet weather conditions in May of 2010 advanced the development of diseases. Nevertheless, the level of the spur and twig blight was low for the cultivars 'Latvijas Zemais' and 'Orlica' (Table 3). The cultivar 'Zentenes' was the most susceptible to the spur and twig blight.

Table 3.

The susceptibility of sour cherry cultivars to the spur and twig blight

\begin{tabular}{|c|c|}
\hline Cultivars & $\begin{array}{c}\text { The susceptibility to the blossom and twig } \\
\text { blight }\end{array}$ \\
\hline 'Latvijas Zemais' & $1.0^{\mathrm{a}}$ \\
\hline 'Orlica' & $1.2^{\mathrm{a}}$ \\
\hline 'Tamaris' & $1.5^{\mathrm{ab}}$ \\
\hline 'Shokoladnica' & $1.7^{\mathrm{ab}}$ \\
\hline 'Bulatnikovskaya' & $2.8^{\mathrm{ab}}$ \\
\hline 'Desertnaya Morozovoi' & $3.3^{\mathrm{b}}$ \\
\hline 'Zentenes' & $7.1^{\mathrm{b}}$ \\
\hline
\end{tabular}

The soil moisture treatments did not influence the susceptibility of cherries to the spur and twig blight in $2010(\mathrm{P} \leq 0.05)$.

The yield of sour cherries was not influenced significantly by incidence of spur and twig blight in 2010. Consequently, the integrated pest management, cultivation technologies and resistance of cherry cultivars was appropriate for controlling of spur and twig blight without losses of the yield.

Symptoms of cherry leaf spot were observed on most of the sour cherry cultivars at the end of active vegetation period in 2009. The average air temperature was in range of the optimum for cherry leaf spot until second decade of the September in 2009. Defoliation of susceptible 
cultivars began in the middle of August and continued during the September. The cultivar 'Tamaris' was the most resistant in this year (Table 4).

Table 4.

The susceptibility of sour cherry cultivars to the cherry leaf spot

\begin{tabular}{|l|l|l|l|}
\hline \multirow{2}{*}{ Cultivars } & \multicolumn{3}{|l|}{ The susceptibility to the cherry leaf spot } \\
\cline { 2 - 4 } & in 2009 & in 2010 & on average \\
\hline 'Latvijas Zemais' & $2.9^{\mathrm{a}}$ & $3.3^{\mathrm{ab}}$ & $3.1^{\mathrm{a}}$ \\
\hline 'Shokoladnica' & $1.9^{\mathrm{b}}$ & $4.2^{\mathrm{a}}$ & $3.1^{\mathrm{a}}$ \\
\hline 'Orlica' & $2.2^{\mathrm{ab}}$ & $2.3^{\mathrm{bcd}}$ & $2.3^{\mathrm{b}}$ \\
\hline 'Zentenes' & $1.5^{\mathrm{b}}$ & $2.9^{\mathrm{bc}}$ & $2.2^{\mathrm{b}}$ \\
\hline 'Desertnaya Morozovoi' & $1.4^{\mathrm{b}}$ & $1.4^{\mathrm{d}}$ & $1.4^{\mathrm{c}}$ \\
\hline 'Bulatnikovskaya' & $1.4^{\mathrm{b}}$ & $1.3^{\mathrm{d}}$ & $1.4^{\mathrm{c}}$ \\
\hline 'Tamaris' & $0.2^{\mathrm{c}}$ & $1.9^{\mathrm{cd}}$ & $1.1^{\mathrm{c}}$ \\
\hline
\end{tabular}

The infection by fungus Blumeriella jaapii Rehm. in 2009 did not affected the yield of sour cherry cultivars in 2010 - the correlation was insignificant. The soil moisture treatments did not influence the susceptibility of cherries to the cherry leaf spot in 2009.

In 2010, the first symptoms of cherry leaf spot appeared already in June due to favourable, wet weather conditions. The average air temperature was in range of the optimum for cherry leaf spot until first decade of the September. The defoliation caused by Blumeriella jaapii Rehm. in 2010 was more pronounced than in 2009. The cultivars 'Bulatnikovskaya' and 'Desertnaya Morozovoi' showed better resistance than the other cultivars in 2010. The cherry leaf spot was not influenced significantly by soil moisture treatments for cultivars 'Bulatnikovskaya', 'Latvijas Zemais', 'Shokoladnica' and 'Desertnaya Morozovoi'. The tendency $(\mathrm{p}=0.06)$ of increased resistance to cherry leaf spot in drip irrigation variant was observed for the cultivars 'Orlica', 'Zentenes' and 'Tamaris' (Figure 2). These cultivars responded to drip irrigation with increased productivity too.

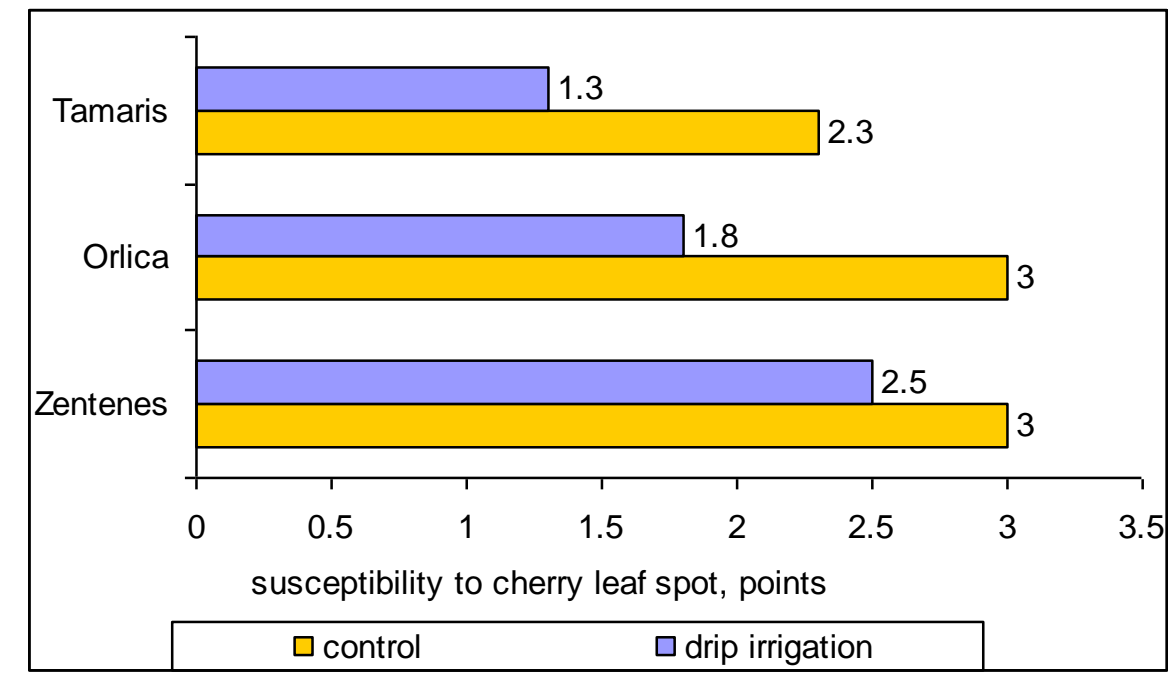

Fig. 2. Influence of drip irrigation to sour cherry suspectibility to cherry leaf spot in 2010

The average evaluation of the susceptibility to the cherry leaf spot was the highest for the cultivar 'Tamaris' and the lowest for the cultivars 'Latvijas Zemais' and 'Shokoladnica'. 


\section{Discussion}

Positive effect of drip irrigation and mulch determined in our research confirms with the results obtained in Poland and in USA [13, 18]. The amount of precipitation was high in our investigation in 2010. Nevertheless, the effect of the mulch was positive. It can be caused by advanced activity of microorganisms and nitrogen mineralization [10], less fluctuations of soil temperature [18] as well as by high water necessity of the cherries.

Drip irrigation caused sour cherry yield increase of $25 \%$ in research carried out in Poland; drip irrigation was applied on 15 years old productive cherry orchard [12]. On average, drip irrigation caused yield increase more than $55 \%$ in our research. Such effect can be explained by the young age of our cherry trees. The vegetative growing was more active then of mature trees, and positive effect of irrigation was more pronounced. The observed tendency of better resistance to cherry leaf spot in drip irrigation variant confirms the water supply necessity in the responses to stress. The differences of resistance among the cultivars were more essential than among soil moisture treatment variants. The disease resistance of cherries is one of main goals in breeding programs in Germany and USA [7, 14].

It must be appointed that positive effect was caused by irrigation managed in previous year. Similarly, positive post-influence of irrigation was observed in research of cherry rootstock 'Colt' [5]. Cuttings of 'Colt' were grown with drip irrigation and compared with non-irrigated rootstocks. The irrigation advanced growth in first growing year. Afterwards rootstocks were replanted and grown without irrigation. However, the previously irrigated plants produced significantly longer total shoot length then previously unirrigated plants.

\section{Acknowledgment}

This study was supported by Europa Social Fund, the agreement 04.4-08/EF2.D1.12.

\section{Summary}

In generally, woodchip mulch and drip irrigation positively influenced yielding of young sour cherries. The cultivars 'Desertnaya Morozovoi', 'Latvijas Zemais' and 'Shokoladnica' was significantly more productive in woodchip mulch variant than in other variants due to rash vegetative growth in previous year. Drip irrigation provided even growth and development of spurs, so it advanced yielding of the cultivars 'Bulatnikovskaya', 'Zentenes', 'Orlica' and 'Tamaris'. The cultivars 'Latvijas Zemais' and 'Orlica' were more resistant to spur and twig blight than other cultivars. 'Bulatnikovskaya' and 'Tamaris' showed better resistance to cherry leaf spot comparing to others. Drip irrigation slightly improved resistance to cherry leaf spot for the cultivars 'Zentenes', 'Orlica' and 'Tamaris'.

\section{Kopsavilkums}

Šķeldu mulča un pilienveida apūdeņošana kopumā labvēlīgi ietekmēja skābo ķiršu jaunkoku ražību. Škeldu mulča būtiski paaugstināja ražību kailzaru ķiršu šķirnēm 'Desertnaja Morozovoi', 'Latvijas Zemais' un 'Šokoladṇica' pateicoties spēcīgajam veǵetatīvajam pieaugumam iepriekšèjā gadā. Pilienveida apūdeņošana nodrošināja vienmērīgu augšanu un pušķzaru attīstību iepriekšējos gados, tādejādi veicinot šķirņu 'Bulatņikovskaja', 'Zentenes', 'Orḷica' un 'Tamaris' ražību. Šķirnes 'Latvijas Zemais' un 'Orḷica' bija izturīgākas pret k̦iršu mēri nekā citas šķirnes. Skābajiem ķiršiem 'Bulatņikovskaja' un 'Tamaris' novērota labāka izturība pret lapbiri salīdzinājumā ar pārējām šķirnēm. Pilienveida apūdeņošanas ietekmē novērota tendence paaugstinātai izturībai pret lapbiri šķirnēm 'Zentenes', 'Orḷica' un 'Tamaris'. 


\section{References}

1. Borovinova, M., Sredkov, I. Comparison of integrated and conventional plant protection of cherry orchards. Notulae Botanicae Horti Agrobotanici Cluj - Napoca, No.34, 2006, p. 93-99.

2. Chaves, M. M., Maroco, J. P., Pereira, J. S. Understanding plant responses to drought- from genes to the whole plant. Functional Plant Biology, No.30, 2003, p. 239-264.

3. Compendium of stone fruit diseases. Edited. by Ogawa J. M.. APS press, 1995, p. 98.

4. Feldmane, D. Effects of irrigation and woodchip mulch on growth and habit of sour cherries. Proceedings of the Annual $15^{\text {th }}$ International Scientific Conference "Research for Rural development 2009", Latvia, 1921 Mai 2009, Jelgava, p. $64-70$.

5. Hipps, N. A., Higgs, K. H., Collard, L. G., Samuelson, T. J. Effects of irrigation and nitrogen fertiliser on the growth and nutrient relations of Prunus avium L. and 'Colt' (Prunus avium $\times$ Prunus pseudocerasus) in the nursery and after transplantation. Annals of forest science, No.51, 1994, p. 433-455.

6. Holb, I. J. Possibilities of brown rot management in organic stone fruit production in Hungary. International Journal of Horticultural Science, 2006, No.12(3), p. 87-91.

7. Iezzoni, A. F., Sebolt, A. M. Sour cherry breeding program at Michigan State University. Acta Horticulturae, No.667, 2005, p.131-133.

8. Jaroszewska, A., Podsiadło, C., Leśniak, E., Kowalewska, R. Productive effects of irrigation and mineral fertilisation in cultivation of some species of stone fruit trees in the region of the Szczecin lowland. Acta Agrophysica, No.13(3), 2009, p. 695-703.

9. Kowalska, J., Remlein-Starosta, D. The first results of Trichoderma asperellum treatment in production of organic sour cherries. Awailable at:

http://www.ecofruit.net/2010/64_SC_J_Kowalska_D_Remlein_Starosta_S384bis387.pdf , 26.02.2011.

10. Nagy, P. T., Kincses I., Lang, T., Szőke, S. L., Nyéki, J. and Szabó, Z. Importance of orchard floor management in organic fruit growing (nutritional aspects). International Journal of Horticultural Science, No.16 (3), 2010, p. 61-67.

11. Pfeiffer, B. Testing of different sour cherry cultivars under organic cultivation. Available at: http://www.ecofruit.net/2010/38_RP_B_Pfeiffer_S254bis258.pdf , 25.02.2011.

12. Rzekanowski, C., Rolbiecki, S. The influence of drip irrigation on yields of some cultivars of stone fruitbearing trees in central Poland under different rainfall conditions during the vegetation season. Acta Horticulturae No.537, 2000, p. 937-942.

13. Sanchez, J. E., Edson, C. E., Bird, G. W., Whalon, M. E., Willson, T. C., Harwood, R. R., Kizilkaya, K., Nugent, J. E., Klein, W., Middleton, A., Loudon, T., Mutch, D. R., Scrimger, J. Orchard floor and nitrogen management influences soil and water quality and tart cherry yields. Journal of the American Society for Horticultural Science, No.128 (2), 2003, p. 277-284.

14. Schuster, M., Wolfram, B. Sour cherry breeding at Dresden-Pillnitz. Acta Horticulturae, No.667, 2005, p. 127. -130 .

15. Süle, S., Seemüller, E. The role of ice formation in the infection of sour cherry leaves by Pseudomonas syringae pv. syringae. Phytopathology, No.77, 1987, p.173-177.

16. Szabó, Z., Szabó, T., Gonda, I., Soltész, M., Thurzó, S., Nyéki, J. 2006. The current situation of sour cherry production and possibilities for develoopment. Available at: http://www.agroinform.com/aktualis/Hungarian-Agricultural-Research-The-current-situation-of-sourcherry-production-and-possibilities-for-develoopment/20061201-621/ , 8.12.2010.

17. Tamm, L., Flückiger, W. Influence or temperature and moisture on growth, spore production, and conidial germination of Monilinia laxa. Phytopathology, No.83, 1993, p.1321-1326.

18. Treder, W., Klamkowski, K., Mika, A., Wojcik, P. Response of young apple trees to different orchard floor management systems. Journal of Fruit and Ornamental Plant Research, No.12, 2004, p. 113-123.

19. Young, J. M., Luketina, R. C., Marshall, A. M. The effects on temperature on growth in vitro of Pseudomonas syringae and Xanthomonas pruni. Journal of Applied Microbiology, No.42, 1977, p.345354. 